\title{
PENGARUH SALES PROMOTION, BRAND IMAGE DAN INSTORE DISPLAY TERHADAP KEPUTUSAN PEMBELIAN (Studi pada Konsumen Hypermarket dan Giant Gresik)
}

\author{
Farah Fauziah \\ Progran Studi Manajemen, Fakultas Ekonomi dan Bisnis, Universitas Muhammadiyah Gresik \\ farah_fauziah@gmail.com
}

\begin{abstract}
This study aims to determine how much the Influence of Sales Promotion, Brand Image and Instore Display towards Consumer Purchasing Decisions on Hypermarket Giant Gresik. The population used in this study were Hypermarket Giant Gresik consumers with a total sample of 96 respondents using Non-Probability Sampling technique with a Incidental Sampling approach. Based on the results of the study found the regression equation as follows $Y=-1.907+0.488 X 1+0.474 X 2+0.567 X 3+e$. Based on statistical data analysis, the indicators in this study are valid and reliable. The variable that has the greatest influence is the Instore Display variable with a regression coefficient of 0.567 . Hypothesis testing uses $t$ test which shows that the three independent variables, namely Sales Promotion (X1), Brand Image (X2), Instore Display (X3), have proven to significantly influence the dependent variable, namely purchasing decision $(Y)$.
\end{abstract}

Keywords: Sales Promotion, Brand Image, Instore Display and Purchase Decision

\section{PENDAHULUAN}

Berbagai cara dilakukan perusahaan untuk mendapatkan keuntungan dan demi mempertahankan suatu bisnis. Perkembangan bisnis ritel di Indonesia bisa dibilang tumbuh sangat pesat sehingga para pengusaha yang telah sukses dalam menjalankan bisnis ritel ini telah membawa banyak kemajuan di negara kita, salah satunya terkait dengan perekonomian di Indonesia yang mengalami peningkatan. Perkembangan perekonomian Indonesia sangat bergantung pada para pebisnis ritel

Menurut Sunyoto (2015), ritel adalah serangkaian kegiatan yang terdiri dari aktivitas aktivitas bisnis yang terlibat dalam menjual barang dan jasa kepada konsumen untuk kepentingan pribadi atau keluarga. Semakin maraknya bisnis ritel yang didirikan di Indonesia serta semakin luas penyebarannya, mulai dari jarak yang ditempuh konsumen menjadi dekat sampai kebutuhan yang dicari konsumen juga tersedia dengan lengkap bukan berarti bisnis ritel akan semakin mudah mencari konsumen. Persaingan antar pebisnis ritel semakin banyak dan menjadikan perusahaan kesulitan untuk mendapatkan pelanggan tetap. Karena jika barang yang dibutuhkan konsumen tidak ada di tokokita maka konsumen akan pindah ke toko lain demi mendapatkan barang yang dibutuhkan. Faktor tersebut menjadikan perkembangan bisnis ritel saat ini bisa dibilang sedang mengalami penurunan.

Faktor pertumbuhan bisnis ritel menurun yang dijelaskan pada berita bisnis tempo.co (2017), Masyarakat lebih memilih belanja lewat internet seperti toko online agar mereka tidak perlu membuang waktu untuk belanja. Berdasarkan berita Aprindo.org (2017), pertumbuhan ritel dari tahun 2011 hingga 2017 telah terjadi penurunan ditiap tahunnya bahkan hanya 1 tahun saja pertumbuhan bisnis ritel mengalami kenaikan pada pertumbuhannya.

Tabel 1

Pertumbuhan Ritel di Indonesia

\begin{tabular}{|l|c|}
\hline \multicolumn{1}{|c|}{ Tahun } & Pertumbuhan \\
\hline $2011-2014$ & $12-15 \%$ \\
\hline 2015 & $8 \%$ \\
\hline 2016 & $9 \%$ \\
\hline 2017 & $3,7 \%$ \\
\hline
\end{tabular}

Sumber: Aprindo.org (2017)

Menurut Ketua Umum Asosiasi Pelaku Ritel Indonesia atau Aprindo mengatakan bahwa 
pertumbuhan ritel mengalami penurunan dari tahun 2011 hingga tahun 2017, namun pada tahun 2016 pertumbuhan ritel sempat mengalami kenaikan. Bisnis ritel dengan kategori hypermarket juga terkena dampak akan melemahnya bisnis ritel saat ini. Dalam menghadapi persaingan yang semakin ketat, Kartanegara (2009:46) menyatakan bahwa setiap perusahaan dipaksa untuk mampu berkompetitif secara sehat dalam mempertahankan peningkatan omzet penjualan. Berdasarkan berita katadata.co.id (2018), Presiden Direktur Hero Supermarket Stephane Deutsch mengatakan industri ritel modern hingga kuartal pertama 2018 masih tetap menantang. Perubahan perilaku konsumen yang lebih ke arah penghematan dalam memutuskan untuk membeli kebutuhan rumah tangga harian mengakibatkan menurunnya bisnis Hero Supermarket.

Menurut Coney dalam Priansa $(2017 ; 61)$ menyatakan bahwa keputusan pembelian merupakan studi mengenai bagaimana individu, kelompok, dan organisasi, dalam proses memilih, mengamankan, menggunakan, dan menghentikan produk, jasa, ide, dan pengalaman untuk memuaskan kebutuhannya, dan dampaknya bagi perusahaan dan konsumen itu sendiri. Keputusan pembelian menurut Suryani (2008;95), dipengaruhi oleh beberapa faktor yaitu produk, harga, promosi, tempat. Sedangkan menurut Tjiptono (2011;235), faktor-faktor yang mempengaruhi keputusan pembelian yaitu nilai emosional, nilai sosial, nilai kualitas dan nilai fungsional. Pada penelitian ini peneliti melakukan penelitian tentang promosi, tempat yang sebagaimana perusahaan mendistribusikan produknya kepada konsumen, dan nilai emosinal yaitu menyangkut suatu merek perusahaan.

Konsumen yang mempunyai pengalaman yang baik terhadap suatu merek atau produk yang dipakai, bisa dilihat dari perusahaan memberikan sesuatu yang lebih terhadap konsumen seperti promosi. Menurut Kotler dan Keller $(2012 ; 219)$ mengatakan bahwa promosi yang merupakan salah satu konsep pemasaran yang dirancang untuk mendorong konsumen agar menstimulasi pembelian yang lebih banyak dan lebih sering yaitu promosi penjualan. Menurut Levy\&Weitz dalam Foster $(2008 ; 70)$, promosi penjualan merupakan intensif khusus dengan melakukan penjualan langsung kepada konsumen akan memberikan dorongan sehingga konsumen memutuskan untuk membeli produk tersebut.
Pada kondisi ini Giant menerapkan strategi pemasaran tersebut dengan mengadakan promosi seperti potongan harga, price packs (menghemat pembelian dengan membeli 2 produk atau lebih), gift (pemberian hadian dengan membeli produk tertentu), dsb melalui katalog promo atau konsumen bisa melihat berbagai promosi di media sosial seperti facebook. Giant juga memberi potongan harga $10 \%$ untuk pembelian produk berlebel Giant kepada pelanggan jika memiliki kartu kredit Bank Permata. Tidak hanya itu saja, Giant memberikan cashback kepada pelanggan yang berbelanja dengan total Rp500.000.

Konsumen dapat belajar atau mengevaluasi tentang bagaimana pengalaman masa lalu dengan produk dan progam pemasarnya sehingga konsumen dapat menilai atau menemukan image mana yang memuaskan kebutuhan dan mana yang tidak (Kotler \& Keller, 2009;259). Kemampuan dalam mengetahui strategi mana yang dilakukan agar produk atau jasa yang dihasilkan bisa memperoleh brand yang baik pada konsumen atau dapat secara berkala melakukan survei kepada publik untuk mengetahui apakah aktivitas-aktivitas perusahaan memperbaiki image-nya disebut juga brand image menurut Amrulah dan Agustin (2016). Menurut Gilaninia dan Mousavian (2012;754) mengatakan bahwa brand image (citra merek) sering digunakan sebagai syarat ekstrinsik untuk membuat sebuah keputusan pembelian. Berikut terdapat peringkat yang menunjukkan bahwa Giant mendapatkan penghargaan di setiap tahunnya:

Tabel 2.

Penghargaan yang diraih oleh Giant

\begin{tabular}{|c|c|}
\hline Tahun & \multicolumn{1}{|c|}{ Award } \\
\hline 2013 & $\begin{array}{c}\text { Great Performing Brand in } \\
\text { Social Media }\end{array}$ \\
\hline 2014 & \multicolumn{2}{|c|}{ Top 50 Companies for 2014 } \\
\hline 2015 & $\begin{array}{l}\text { 1. Giant sebagai Indonesia Best } \\
\text { Brand Platinum Versi } \\
\text { Indonesia. }\end{array}$ \\
\hline 2016 & 2. Superbrands Giant \\
\hline 2017 & $\begin{array}{l}\text { Indonesian Brand: Bronze } \\
\text { Champion }\end{array}$ \\
\hline
\end{tabular}

\section{Sumber: https://hero.co.id/award}

Brand image perusahan akan mempengaruhi pemilihan produk dan jasa oleh konsumen, dengan brand image yang baik konsumen akan mudah membedakan antar jasa 
yang pernah memuaskan kebutuhan konsumen dan jasa yang tidak sesuai kebutuhan. Usaha perusahaan dalam meningkatkan keunggulan mereknya melalui kegiatan pemasaran seperti memperkenalkan dan menarik konsumen untuk memutuskan pembelian disebut juga display (Sopiah dan Syihabuddin, 2008;238). Menurut Putri (2008), display atau pemajangan barang/produk adalah penataan barang dagangan pada tempat tertentu dengan tujuan agar dapat menarik konsumen untuk melihat dan akhirnya membeli produk yang akan ditawarkan. Penempatan barang pada perusahaan dapat memiliki nilai lebih terhadap konsumen, karena konsumen akan merasa termudahkan ketika perusahaan menempatkan barang dagangan sesuai dengan jenisnya. Penempatan barang juga termasuk dalam penataan barang atau display, pengertian display yaitu memberikan informasi kepada konsumen mengenai informasi produk yang dijual (Sopiah dan Syihabudhin;2008).

Hal yang perlu diperhatikan oleh perusahaan dalam penataan produk, menurut Sopiah dan Syihabudhin (2008) seperti simbol simbol yang menginformasikan masing - masing departemen dan kartu harga yang menginformasikan mengenai harga. Hal tersebut juga dilakukan oleh Giant, sehingga konsumen mudah untuk mendapatkan produk yang dicari.Simbol harga pada display yang menunjukkan bahwa produk tersebut terdapat promo akan dipamerkan oleh perusahaan.

Setiap permasalahan yang ada di Giant, jika perusahaan tidak dengan segera memperbaiki apa yang menjadi masalah pada perusahaan akan berakibat pada pengulangan masalah ini kembali. Maka dari itu, perusahaan dianjurkan untuk memperhatikan strategi pemasaran yang digunakan oleh perusahaan agar tidak mengulangi permasalahan tersebut. Berdasarkan latar belakang yang telah diuraikan diatas, maka penulis tertarik untuk melakukan penelitian mengenai "Pengaruh Sales Promotion, Brand Image dan Instore Display terhadap Keputusan Pembelian di Hypermarket Giant Gresik"

Berdasarkan latar belakang diatas, maka perumusan masalah dalam penelitian sebagai berikut:

1. Apakah sales promotion berpengaruh secara parsial terhadap keputusan pembelian pada hypermarket Giant Gresik?
2. Apakah brand image berpengaruh secara parsial terhadap keputusan pembelian pada hypermarket Giant Gresik?

3. Apakah instore display berpengaruh secara parsial terhadap keputusan pembelian pada hypermarket Giant Gresik?

\section{PEMBAHASAN}

Penelitian sebelumnya yang digunakan peneliti adalah sebagai dasar dalam penyusunan penelitian berikutnya, yaitu:

1. Fadhli Nurfakhrusy (2017). "Pengaruh periklanan, promosi penjualan dan penjualan personal pada keputusan pembelian (studi pada motor yamaha fino di PT. Lautan Teduh Sentral Yamaha Bandar lampung)". Hasil penelitian dengan menggunakan uji $t$ menunjukkan bahwa periklanan, promosi penjualan dan penjualan personal memiliki pengaruh yang signifikan pada keputusan pembelian. Dan pada hasil uji f memperoleh hasil berpengaruh secara bersama-sama.

2. Era aptisa dina wijayana (2017). "Pengaruh atmosfer toko, display dan harga terhadap keputusan pembelian konsumen pada distro downright kediri". Hasil penelitian menunjukkan bahwa atmosfer toko, display dan harga berpengaruh signifikan terhadap keputusan pembelian konsumen. Dan pada uji f menunjukkan bahwa variabel independen secara bersama - sama berpengaruh terhadap variabel dependen.

3. Amalia Sulistiana dan Harrie Lutfie (2017). "Pengaruh advertising dan citra merek terhadap keputusan pembelian pada fashion hijab elzatta di kota bandung (Studi Kasus Konsumen Elzatta Bandung)". Hasil penelitian menunjukkan bahwa variabel advertising dan citra merek memiliki pengaruh yang signifikan secara parsial terhadap keputusan pembelian. dan pada uji $\mathrm{f}$ menunjukkan bahwa variabel independen secara bersama - sama berpengaruh terhadap variabel dependen.

\section{Keputusan Pembelian}

Menurut Coney (dikutip oleh Priansa, 2017:61) menyatakan bahwa keputusan pembelian merupakan studi mengenai bagaimana individu, kelompok, dan organisasi, dalam proses memilih, 
mengamankan, menggunakan, dan menghentikan produk, jasa, ide, dan pengalaman untuk memuaskan kebutuhannya, dan dampaknya bagi perusahaan dan konsumen itu sendiri. Menurut Kotler dan Amstrong dalam Priansa (2017; 88), proses keputusan pembelian melalui berbagai tahapan, yaitu: pengenalan masalah, pencari informasi, evaluasi alternatif, keputusan pembelian dan perilaku pasca pembelian. Menurut Suryani (2008 : 95) faktor - faktor yang memoengaruhi keputusan pembelian yaitu: produk, promosi, harga dan tempat, sedangkan Tjiptono (2011: 235) terdiri dari: nilai emosional, nilai sosial, nilai kualitas dan nilai fungsional. Menurut Kotler\&Keller $(2008 ; 188)$, indikator keputusan pembelian yaitu: merek, penyalur, kuantitas dan metode pembayaran.

\section{SALES PROMOTION}

Belch dalam Foster $(2008 ; 68)$ mengemukakan bahwa promosi penjualan merupakan aktivitas pemasaran langsung yang memberikan nilai lebih atau intensif kepada tenaga penjual, distributor atau konsumen akhir dan dapat menstimulasi penjualan langsung.Terdapat berbagai alat yang dapat digunakan guna untuk mencapai tujuan promosi penjualan, berikut beberapa alat promosi penjualan terhadap konsumen (consumer promotion) yang menurut Kotler dalam Foster (2008;71) diantaranya:samples, coupon, cash refund offers, price packs, gifts, frequency programs, prizes, patronage awards, free trial, product warranties, tie-in promotions, crosspromotions. Hermawan $(2012 ; 128)$ menyatakan bahwa terdapat beberapa indikator yang dapat diukur, yaitu: Komunikasi, insentif dan menarik pembeli.

\section{BRAND IMAGE}

Menurut Aeker (dikutip oleh Buchori;2013:148) menyatakan, brand image akan terbentuk dalam jangka waktu tertentu karena merupakan akumulasi persepsi suatu objek, apa yang terpikirkan diketahui dialami yang masuk dalam memori seseorang berdasarkan masukanmasukan dari berbagai sumber sepanjang waktu. Menurut Kotler (dikutip oleh Buchari;2013:157), brand memiliki enam tingkatan pengertian: atributes, benefit, values, culture, personality dan user. Indikator yang digunakan untuk mengukur Citra Merek adalah indikator yang disebutkan Ferrinadewi $(2008 ; 167)$ adalah memiliki brand yang positif, atribut brand mudah diingat, atribut brand mudah disebut.

INSTORE DISPLAY
Menurut Putri (2008) dalam bukunya "Evaluasi Penataan atau Display Produk", mengatakan bahwa pemajangan barang/produk (display) adalah penataan barang dagangan pada tempat tertentu dengan tujuan agar dapat menarik konsumen untuk melihat dan akhirnya membeli produk yang akan ditawarkan. Berikut ini teknik display yang baik adalah sebagai berikut (Sopiah dan Syihabudhin, 2008 : 238): bulk, ends, special display, island, cut- cases, jumled display,multi product, tie ins, shelt extenderst. Menurut Gerard J Tellis (2011:237) elemen penting dari display (indikator): product supplying (ketersediaan barang), product grouping (pengelomppokkan barang), product arranging (penyusunan barang).

\section{Hubungan Antar Variabel \\ Hubungan Sales Promotion terhadap Keputusan Pembelian}

Menurut Mauri dalam Omar, et al $(2011 ; 23)$ menyatakan bahwa promosi penjualan termasuk program promosi dimana dapat memberikan rangsangan bagi konsumen untuk melakukan pembelian. Untuk itu, promosi penjualan memiliki fungsi yang relatif sama dengan promosi karena program tersebut akan memberikan daya tarik bagi konsumen untuk melakukan pembelian.

\section{Hubungan Brand Image Terhadap Keputusan} Pembelian

Brand image menurut Sutojo dalam Ardianto (2011:72), kemampuan dalam mengetahui strategi mana yang dilakukan agar produk atau jasa yang dihasilkan bisa memperoleh citra yang baik pada konsumen atau citra yang positif dapat mempengaruhi konsumen dalam membeli produk atau jasa. Untuk itu, citra merek dapat menjadi salah satu faktor yang harus dipertimbangkan oleh konsumen dalam melakukan keputusan pembelian. Gilaninia dan Mousavian $(2012 ; 754)$ mengatakan bahwa brand image (citra merek) sering digunakan sebagai syarat ekstrinsik untuk membuat sebuah keputusan pembelian. Jika konsumen tidak memiliki pengalaman dengan suatu produk, mereka cenderung untuk mempercayai merek yang disukai atau yang terkenal, (Schiffman dan Kanuk, 2008 : 173).

\section{Hubungan Instore Display terhadap Keputusan Pembelian}

Menurut Sopiah dan Syihabuddin (2008;238), Display adalah "usaha yang dilakukan untuk menata barang yang mengarahkan pembeli agar tertarik untuk melihat dan memutuskan untuk membelinya". Jadi Display adalah menata barang-barang yang akan ditawarkan kepada 
konsumen, dengan penataan yang menarik dan unik membuat konsumen tertarik dan melakukan kegiatan pembelian suatu produk.

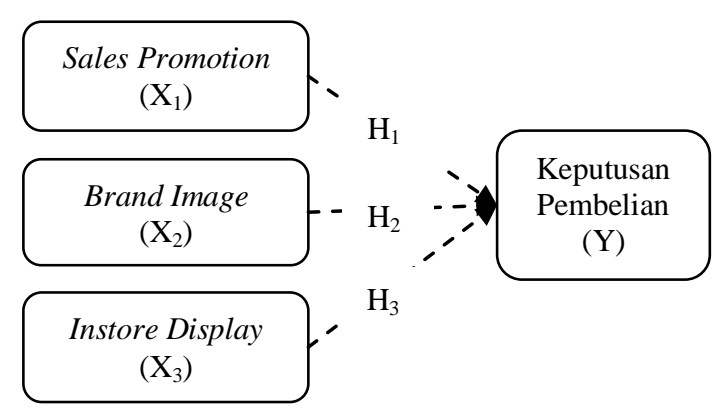

KERANGKA KONSEPTUAL

\section{Keterangan :}

- $\rightarrow$ Berpengaruh secara Parsial

\section{HIPOTESIS}

Berdasarkan pemaparan kerangka pemikiran di atas, maka hipotesis yang diajukan dalam penelitian adalah:

1. $\mathrm{H}_{1}$ : Diduga varibel Sales Promotion memiliki pengaruh secara parsial terhadap Keputusan Pembelianpada hypermarket Giant Gresik.

2. $\mathrm{H}_{2}$ : Diduga varibel Brand Image memiliki pengaruh secara parsial terhadap Keputusan Pembelian pada hypermarket Giant Gresik.

3. $\mathrm{H}_{3}$ : Diduga varibel Instore Display memiliki pengaruh secara parsial terhadap Keputusan Pembelian pada hypermarketGiant Gresik

\section{METODOLOGI PENELITIAN}

Jenis penelitian yang digunakan dalam penelitian ini adalah penelitian kuantitatif. Object Penelitian ini dilakukan di Hypermarket Giant Jl. Kalimantan, Yosowilangun, Kec. Gresik, Kabupaten Gresik, Jawa Timur 61112. Populasi pada penelitian ini adalah konsumen yang pernah melakukan pembelian di hypermarket Giant Gresik. Pengambilan sampel dari populasi yaitu sebesar 96 responden dengan menggunakan metode nonprobability sampling melalui teknik sampling incidental. Definisi operasional atau sering dinamakan juga sebagai operasionalisasi variabel menurut Zulganef $(2013 ; 84)$ adalah kegiatan atau proses yang dilakukan peneliti untuk mengurangi tingkat abstraksi konsep sehingga konsep tersebut dapat diukur. Dalam penelitian ini variabel yang akan dianalisis yaitu variabel independen yang terdiri dari sales promotion dengan indikator komunikasi, insentif dan menarik pembeli.Brand imagedengan indikator memiliki brand yang positif, atribut brand mudah diingat dan atribut brand mudah disebut. Instore displaydengan indikator product supplying, product grouping, product arranging.serta variabel dependen yaitu keputusan pembelian dengan indikator merek, penyalur, kuantitas dan metode pembayaran. Metode pengumpulan data menggunakan jenis data primer yang dikumpulkan dari metode survei dalam bentuk kuisoner. Teknik analisis data yang dipakai analisis regresi linier berganda.Pada penelitian ini menggunakan tiga alat uji yaitu Uji instrumen dibagi menjadi 2 yaitu uji validitas dan uji reliabilitas, Uji asumsi klasik dibagi menjadi 3 yaitu uji normalitas, uji multikolinieritas, uji heteroskedasitas, dan uji hipotesis dibagi menjadi 2 yaitu uji parsial (uji t) dan uji $\mathrm{F}$ (simultan).

\section{HASIL PENELITIAN DAN PEMBAHASAN}

\section{Sejarah Hypermarket Giant Gresik}

Giant merupakan perusahaan yang berada dibawah naungan PT.Hero Supermmarket. PT. Hero Supermarket memperluas jaringan perusahaannya dengan membuka Giant sebagai segmen hypermarket Hero. Giant Hypermarket dibuka untuk mengakomodasi entusiasme publik untuk berbelanja dengan pelayanan yang baik dengan harga yang hemat. Gerai giant yang pertama kali dibuka di Indonesia adalah Giant Hypermarket di Villa Melati Mas, Serpong, Tangerang pada tanggal 26 Juli 2002.

\section{Visi Dan Misi Hypermarket Giant Gresik}

\section{Visi}

Menjadi pengecer terkemuka di Indonesia dari segi penjualan dan penciptaan nilai jangka panjang bagi para pemangku kepentingan.

2. Misi

a. Kami memiliki 5 merek toko (Hero Supermarket, Guardian, Starmart,Giant Ekstra dan Giant Ekspres) yang dapat memuaskan semua segmen pelanggan dan kami akan mengembangkannya secara menguntungkan di seluruh Indonesia, dengan memperkuat penawaran masing-masing merek toko.

b. Kami meningkatkan dan memotivasi talenta lokal terbaik dalam Perseroan. 
c. Kami berusaha keras menjadi yang terbaik bagi pelanggan, lebih sederhana bagi karyawan, dan lebih murah bagi Perseroan.

d. Kami, sebagai pelopor ritel di Indonesia akan melanjutkan bekerja sama untuk tumbuh seiring dengan perkembangan negara kami, memajukan perseroan kami dan meningkatkan kesejahteraan para pemangku kepentingan

Deskripsi Hasil Penelitian

Karakteristik Responden

Karakteristik Responden Berdasarkan Usia

\begin{tabular}{|c|c|c|}
\hline Usia & $\begin{array}{c}\text { Jumlah } \\
\text { (Orang) }\end{array}$ & $\begin{array}{c}\text { Persentase } \\
(\mathbf{\%})\end{array}$ \\
\hline $16-21$ tahun & 8 & 8 \\
\hline $22-27$ tahun & 14 & 15 \\
\hline $28-33$ tahun & 17 & 18 \\
\hline $34-39$ tahun & 17 & 18 \\
\hline $40-45$ tahun & 18 & 19 \\
\hline $46-51$ tahun & 11 & 11 \\
\hline $52-57$ tahun & 6 & 6 \\
\hline $58-63$ tahun & 5 & 5 \\
\hline Total & $\mathbf{9 6}$ & $\mathbf{1 0 0}$ \\
\hline
\end{tabular}

Tabel 4.1 menunjukkan jumlah dan persentase usia responden dalam penelitian ini yaitu didominasi usia 40 - 45 tahun dengan jumlah responden sebanyak 18 orang dan persentase19\%. Sehingga konsumen yang melakukan pembelian di Giant lebih dominan pada usia 40 - 45 tahun.

\section{Karakteristik Responden Berdasarkan Jenis} Kelamin

\begin{tabular}{|c|c|c|}
\hline $\begin{array}{c}\text { Jenis } \\
\text { Kelamin }\end{array}$ & $\begin{array}{c}\text { Jumlah } \\
\text { (Orang) }\end{array}$ & Prosentase\% \\
\hline Laki-laki & 17 & 18 \\
\hline Perempuan & 79 & 82 \\
\hline Total & 96 & 100 \\
\hline
\end{tabular}

Berdasarkan tabel 4.2 dapat dilihat bahwa responden terbanyak adalah responden yang berjenis kelamin perempuan yaitu sebanyak 79 orang responden dengan persentase $82 \%$ dan 17 responden berjenis kelamin laki - laki dengan persentase $18 \%$.

\section{UJI INSTRUMEN \\ Uji Validitas}

Pada penelitian ini digunakan kuesioner untuk mengumpulkan data penelitian. Suatu kuesioner dikatakan valid jika pernyataan pada kuesioner mampu untuk mengungkapkan sesuatu yang akan diukur oleh kuesioner tersebut. Dalam uji validitas isi suatu butir pernyataan atau variabel dinyatakan valid jika $r_{\text {hitung }}$ lebih besar dari $r_{\text {tabel }}$.
Dari hasil uji validitas instrumen semua variabel didapatkan rhitung > rtabel 0,2006. Jadi seluruh butir pernyataan menunjukan bahwa seluruh indikator pernyataan dalam variabel sales promotion, brand image, instore display dan keputusan pembelian lebih besar dari 0,2006 sehingga seluruh indikator tersebut telah memenuhi syarat validitas data sehingga indikator-indikator dalam penelitian ini mampu sebagai pembentuk pada masing-masing variabel.

\section{Uji Reliabilitas}

Reliabilitas dikatakan reabilitas apabila memiliki nilai Cronbach Alpha > 0,60 Ghozali, 2009;16). Berdasarkan hasil perhitungan yang dilakukan dengan aplikasi SPSS, pengujian reliabilitas dapat disimpulkan bahwa variabel sales promotion diperoleh nilai 0.836 , brand image diperoleh nilai sebesar 0.647 , instore display diperoleh nilai 0.623 dan keputusan pembelian diperoleh nilai sebesar 0.818 . Keempat variabel tersebut memiliki koefisien Cronbach Alpha lebih besar dari 0,60 sehingga pernyataan pada kuesoner tersebut reliabel.

\section{UJI ASUMSI KLASIK}

\section{Uji Multikolinearitas}

Uji multikolineritas dalam penelitian ini dengan menggunakan dasar pengambilan keputusan, Jika nilai Variance Inflation Factor (VIF) tidak lebih dari 10 dan nilai Tolerance (TOL) tidak kurang dari 0.1, maka model dapat dikatakan terbebas dari multikolineritas (Ghozali, 2016;106).

\section{Uji Heteroskedastisitas}

Untuk melihat adanya heteroskedastisitas adalah dengan menggunakan uji statistik. Uji statistik yang dipilih adalah uji Glejser, dasar pengambilan keputusan uji heteroskedastisitas melalui uji Glejser adalah apabila hasil sig > 0,05 maka tidak terdapat gejala heteroskedastisitas, (Ghozali, 2013;143).Hasil uji Glejser Sales Promotion $\left(\mathrm{X}_{1}\right)$ 0.105, Brand Image $\left(\mathrm{X}_{2}\right) 0.577$ dan Instore Display ( $\left.\mathrm{X}_{3}\right) 0.086$ hal tersebut menunjukan tidak terdapat gejala heteroskedastisitas karena hasil sig. $>0.05$.

\section{Uji Normalitas}

Uji normalitas dalam penelitian ini dengan menggunakan analisis uji Kolmogorov-Smirnov Test. Distribusi1).Jika nilai Asymp. Sig. (2tailed) lebih besar dari nilai 0.05 maka dapat dikatakan bahwa distribusi normal ; 2) Asymp. Sig. (2-tailed) lebih kecil dari nilai 0.05 maka dapat dikatakan bahwa distribusi tidak Normal. Hasil uji Kolmogorov-Smirnov Testdi ketahui nilai Signifikansi $0.652>0.05$ sehingga dapat disimpulkan data berdistribusi normal, maka 
model regresi yang digunakan dalam penelitian ini memenuhi asumsi normalitas.

\section{ANALISIS DATA}

\section{Regresi Linear Berganda}

Analisis ini digunakan untuk mengetahui apakah variabel sales promotion, brand imagedan instore display berpengaruh terhadap Keputusan Pembelian di hypermarketGiant Gresik yang dilihat dari tabel dengan melihat pada kolom B yang menghasilkan persamaan regresi linier berganda diatas dapat dijelaskan sebagai berikut: $\mathrm{Y}=-1.907+0.488 \mathrm{X}_{1}+0.474 \mathrm{X}_{2}+0.567 \mathrm{X}_{3}+\mathrm{e}$

\section{Koefisien Determinasi $\left(\mathbf{R}^{2}\right)$}

Koefisien korelasi (R) memperoleh nilai sebesar 0.679 , dimana $\mathrm{R}$ digunakan untuk mengetahui hubungan antar variabel bebas (X) terhadap variabel terikat $(\mathrm{Y})$ secara bersama. Koefisien determinasi $\left(\mathrm{R}^{2}\right)$ memperoleh nilai sebesar 0.444 , dimana adjusted $\mathrm{R}^{2}$ digunakan untuk mengukur seberapa jauh kemampuan model dalam menerangkan variasi variabel independen.

\section{UJI HIPOTESIS}

\section{Uji t}

Uji ini digunakan untuk menguji seberapa jauh satu variabel bebas (independen) secara individual dalam menerangkan variasi variabel terikat (dependen).

\section{Hasil Analisis Uji Parsial (Uji T) Variabel Sales Promotion}

Nilai thitung sebesar 4.926 sedangkan t tabel sebesar 1,985. Hasil ini menunjukan bahwa $t$ hitung $>\mathrm{t}$ tabel dengan signifikan sebesar 5\%. Dengan demikian hasil perhitungan statistik menunjukan bahwa secara parsial variabel sales promotion $\left(\mathrm{X}_{1}\right)$ terbukti berpengaruh signifikan terhadap keputusan pembelian pada hypermarket Giant Gresik (Y).

\section{Hasil Analisis Uji Parsial (Uji T) Variabel Brand Image}

Nilai thitung sebesar 2.558 sedangkan t tabel sebesar 1,985. Hasil ini menunjukan bahwa $t$ hitung > t tabel dengan signifikan sebesar 5\%. Dengan demikian hasil perhitungan statistik menunjukan bahwa secara parsial variabel brand image $\left(\mathrm{X}_{2}\right)$ terbukti berpengaruh signifikan terhadap keputusan pembelian pada hypermarket Giant Gresik (Y).

\section{Hasil Analisis Uji Parsial (Uji T) Variabel Instore Display}

Nilai thitung sebesar 2.558 sedangkan t tabel sebesar 1,985. Hasil ini menunjukan bahwa $t$ hitung $>\mathrm{t}$ tabel dengan signifikan sebesar 5\%. Dengan demikian hasil perhitungan statistik menunjukan bahwa secara parsial variabel brand image $\left(\mathrm{X}_{2}\right)$ terbukti berpengaruh signifikan terhadap keputusan pembelian pada hypermarket Giant Gresik (Y).

a. Hasil penelitian terhadap variabel Sales Promotion $\left(\mathrm{X}_{1}\right)$ diperoleh $\mathrm{t}$ hitung sebesar $4.926>\mathrm{t}$ tabel sebesar 1.985dengan taraf signifikansi 5\%, maka terbukti bahwa Sales Promotion $\left(\mathrm{X}_{1}\right)$ berpengaruh signifikan terhadap keputusan pembelian pada hypermarketGiant Gresik. Hal ini disebabkan oleh informasi yang diberikan oleh Giant mengenai promosi suatu produk kepada konsumennya sudah jelas, banyaknya promosi yang diberikan Giant seperti potongan harga, price pack (beli 1 gratis 1), dan gift (pemberian hadiah) sehingga konsumen akan tertarik untuk melakukan pembelian di hypermarket Giant Gresik. Dilihat dari hasil tanggapan penilaian responden tentang sales promotion pada tabel 4.4, konsumen lebih dominan menjawab setuju dengan promosi yang diberikan oleh Giant.

b. Hasil penelitian terhadap variabel brand image $\left(\mathrm{X}_{2}\right)$ diperoleh thitung sebesar $2.558>$ $\mathrm{t}$ tabel sebesar1.985dengan taraf signifikansi 5\%, maka terbukti bahwa brand image $\left(\mathrm{X}_{2}\right)$ berpengaruh signifikan terhadap keputusan pembelian pada hypermarket Giant Gresik. Hal ini disebabkan karena Giant yang telah menjaga nama baik perusahaan dan telah mempertahankan penghargaan yang telah diraih sehingga konsumen akan selalu mengingat brand Giant merupakan perusahaan yang dipilih dalam keputusan pembelian. Pernyataan tersebut juga dapat dilihat dari hasil tanggapan penilaian responden tabel 4.5, dimana responden setuju dengan citra merek pada Giant.

c. Hasil penelitian terhadap variabel instore display $\left(\mathrm{X}_{3}\right)$ diperoleh $\mathrm{t}$ hitung sebesar 3.689 $>\mathrm{t}$ tabel sebesar1.985dengan taraf signifikansi $5 \%$, maka terbukti bahwa instore display $\left(\mathrm{X}_{3}\right)$ berpengaruh signifikan terhadap keputusan pembelian pada hypermarket Giant Gresik. Hal ini di sebabkan karena konsumen telah merasa nyaman dengan lingkungan Giant yang terlihat bersih serta rapi dalam penataan barang yang sesuai dengan jenis produk yang serupa, dan Giant juga menyediakan berbagai macam produk yang dijual sehingga 
konsumen memberi tanggapan setuju dengan instore display pada Giant Gresik yang dapat dilihat dari hasil tanggapan penilaian responden pada tabel 4.6.

d. Hasil penelitian yang diperoleh dari koefisien determinasi $\left(\mathrm{R}^{2}\right)$ diperoleh hasil Adjusted $\mathrm{R}$ Square sebesar 0.444 dimana nilai tersebut mempunyai arti bahwa variabel independen Sales Promotion $\left(\mathrm{X}_{1}\right)$, Brand Image $\left(\mathrm{X}_{2}\right)$ dan Instore Diplay $\left(\mathrm{X}_{3}\right)$ yang menjelaskan variasi variabel dependen keputusan pembelian (Y) yaitu sebesar $44.4 \%$. Sedangkan sisanya sebesar $43.4 \%$ dapat dijelaskan oleh faktorfaktor lain diluar variabel tersebut. Nilai Adjusted R Square yang kecil berarti kemampuan variabel independen dalam menjelaskan variabel dependen yaitu rendah. Jika nilai R Square kecil artinya komponen error bernilai besar. Nilai error yang pada penelitian ini bisa dilihat dari nilai standard error of the estimate 1.690, hal ini berarti banyaknya kesalahan dalam memprediksi faktor yang mempengaruhi konsumen dalam keputusan pembelian sebesar 1.69\%.

\section{KESIMPULAN}

Berdasarkan hasil analisis data dan interpresentasi hasil maka kesimpulan yang diambil dari penelitian dengan judul berjudul "Pengaruh Sales Promotion, Brand Image dan Instore Display terhadap Keputusan Pembelian pada hypermarket Giant Gresik (Studi Pada Konsumen hypermarket Giant Gresik)" adalah sebagai berikut:

1. Sales Promotion berpengaruh secara parsial terhadap keputusan pembelian pada Hypermarket Giant Gresik.

2. Brand Image berpengaruh secara parsial terhadap keputusan pembelian pada Hypermarket Giant Gresik.

3. Instore Display berpengaruh secara parsial terhadap keputusan pembelian pada Hypermarket Giant Gresik.

\section{SARAN}

1. Bagi Perusahaan

Berdasarkan perhitungan uji $\mathrm{t}$ variabel instore display $\left(\mathrm{X}_{3}\right)$ memiliki nilai koefisien sebesar 0.567 yang artinya tertinggi dari variabel sales promotion $\left(\mathrm{X}_{1}\right)$ dan brand image $\left(\mathrm{X}_{2}\right)$, maka pihak perusahaan ketika terjadi perubahan harga baik dalam penurunan dan kenaikan harga atau adanya produk yang sedang promo sebaiknya tidak hanya merubah pada mesin cashier saja melainkan mengecek dan mengganti harga yang sudah tertera di display apabila terjadi perubahan, serta memberikan informasi apabila terdapat produk yang sedang promo.

2. Bagi Peneliti Selanjutnya

Bagi peneliti selanjutnya hasil penelitian ini dapat digunakan sebagai referensi bagi peneliti selanjutnya dengan memperbanyak jumlah variabel - variabelnya dan menggunakan teknik analisis yang berbeda.

\section{DAFTAR PUSTAKA}

Akhmad, Ali. 2017. "Pertumbuhan Sektor Ritel 2017 Lebih Rendah dibanding 2016" diakses pada tanggal 17 Oktober 2017 dari https://bisnis. tempo.co/read/1025310/aprindo pertumbuhan-sektor-ritel-2017-lebihrendah-dari-2016.

Amrullah, AR., dan Agustin, S. 2016. Pengaruh Kualitas Produk, Harga dan Citra Merek Terhadap Keputusan PembelianHonda Beat". Jurnal Ilmu dan Riset Manajemen. Vol 5, No 7:115.

Anonim. 2016. "Ratusan Toko Modern Bercokol di Gresik" diakses pada tanggal 28 Februari 2018 dari http:// www.beritametro.news/ epaper/ gresik/ ratusan-toko-modern-bercokol-digresik. 